ISSN 1518-3483

Licenciado sob uma Licença Creative Commons

\title{
Interaction university and school: a collaboration between action and speeches
}

\section{Interação universidade e escola: uma colaboração entre ações e discursos}

\begin{abstract}
Gionara Tauchen $^{[a]}$, Catia Piccolo Viero Devechi ${ }^{[b]}$, Amarildo Luiz Trevisan $^{[c]}$
[a] PhD in Education from Pontifícia Universidade Católica do Rio Grande do Sul, professor in the Programa de Pós-Graduação em Educação at the Universidade Federal do Rio Grande (FURG), Rio Grande, RS - Brazil, e-mail: gionaratauchen@furg.br

[b] PhD in Education from the Universidade Federal de Santa Catarina, professor in the Programa de Pós-Graduação em Educação at the Universidade de Brasília (UnB), Brasília, DF - Brazil, e-mail: devechi@unb.br

[c] PhD in Education from the Universidade Federal do Rio Grande do Sul (UFRGS), professor in the Programa de Pós-Graduação em Educação at the Universidade Federal de Santa Maria (UFSM), Santa Maria, RS - Brazil, e-mail: trevisanamarildo@gmail.com
\end{abstract}

\section{Abstract}

Considering that the interaction between universities and middle schools is fundamental for organization and the qualification of the education system, we conducted a qualitative study on twenty public municipal schools of Rio Grande, RS, designed to investigate and understand 
the effectiveness of university activities (teaching, research and extension) in regard to the promotion and strengthening of the interactions between these institutions. We highlight the activities related to Pibid, the Education Observatory, extension, supervised internships, and to undergraduate and postgraduate research. From comprehensions about these activities we discuss, from the Habermasian purposes, the possibilities of knowledge continuity between pragmatic and epistemological knowledge in order to improve the learning performance, facing demands to improve the interaction between school and university.

Keywords: Communicative learning. University. School. Interaction.

\section{Resumo}

Considerando que a interação entre a universidade e a Escola Básica é fundamental tanto à organização quanto à qualificação do sistema educacional, realizamos uma pesquisa qualitativa com 20 escolas municipais urbanas do município de Rio Grande (RS), com o objetivo de investigar e compreender a efetividade das atividades universitárias (ensino, pesquisa e extensão), no que se refere à promoção e ao fortalecimento das interações entre as instituições. Destacam-se as atividades vinculadas ao Pibid, ao Observatório da Educação, à extensão, aos estágios supervisionados e à pesquisa na graduação e na pósgraduação. A partir das compreensões sobre essas atividades, buscamos discutir, balizadas nos propósitos habermasianos, as possibilidades de continuidade entre saberes pragmáticos e saberes epistemológicos, no sentido de um melhor desempenho da aprendizagem diante das reivindicações de melhoria da interação entre escola e universidade.

Palavras-chave: Aprendizagem comunicativa. Universidade. Escola. Interação.

\section{Initial considerations}

Interaction among the levels and modalities that comprise the National Education System has been described as crucial by both 
public policy and various public sectors because it is associated with the processes of democratization, access, sustainability and education quality. The desire to promote this interaction has increasingly initiated discussions about the effects of university activities on the quality of both university and primary school education, on the centralization and bureaucratization of educational management processes, and on the lack of cooperation among schools in the development of research and other activities. In addition, schools have criticized the limited effectiveness of university research, the structure of internships, the lack of continuity among university initiatives, and the lack of collaborative efforts to mediate teaching situations. Such dissatisfaction can be found from the Ministry of Education (MEC) to Capes [Coordenação de Aperfeiçoamento de Pessoal de Nível Superior] and from universities to primary schools. It has prompted a reconsideration of the relationships between these institutions, with an especial focus on improving elementary school education. However, should closeness and interaction between higher education and elementary education be developed between the systems, the institutions, the activities they perform or among the people who comprise them? What potential does social interaction have? How can it be promoted? Lüdke, Rodrigues and Portela (2012) have offered the concept of "knowledge circularity" as an alternative to the concept of knowledge circulation commonly associated with the principle of knowledge transfer. Knowledge circularity has been examined in research on teachers and has been shown to increase communication between universities and elementary schools.

To contribute to this discussion, this study determines how municipal school principals in Rio Grande (RS), primary schools perceived the effectiveness of university activities (teaching, research and outreach) in promoting and strengthening interactions among educational levels. Principals are important mediators of schools' internal and external relations, contributing to the development of partnerships with universities and evaluating the effectiveness of their schools' academic activities. This qualitative study (MINAYO, 2001) 
conducted semi-structured interviews with twenty (20) principals and used content analysis (BARDIN, 1977; FRANCO, 2008) to identify the activities that contribute to strengthening the interactions between universities and primary schools and the main challenges and difficulties of such endeavors. Statements from these interviews will be presented throughout the text, and the speakers are identified by a code to preserve their anonymity.

After identifying the perceived difficulties of university-school interaction, the possibility of greater collaboration between schools and universities is discussed using Habermas's theory of the association between action and discourse presented in Truth and Justification. Habermas proposes that the relationship between action and discourse be treated as an epistemological-pragmatic relationship between problematization and deproblematization to create a retroactive, recursive, and regenerative circularity. In other words, a space for exchange should be established between actions capable of verifying effective convictions and a discourse capable of argumentatively deproblematizating flawed knowledge. To achieve this, the continuity between action and discourse should be studied in the context of improving practical and theoretical learning performance to verify claims of improved interaction between institutions.

\section{Circularity between action and discourse}

Habermas proposes an association between the epistemological truths developed through discourse and the pragmatic truths that result from linguistic action in the world. He seeks to establish the fallibility of discourse and does not believe in the possibility of irreversible reason. Therefore, he imagines a world that resists human actions. Nevertheless, human practices require certainty, without which reliable action would not be possible. This includes certainty achieved through sustainable action: "the reliability of expectations subjectively immune 
to disappointment does not support any conscious fallibilist reserve during action" (HABERMAS, 2004a, p. 49). According to Habermas, daily practices cannot be treated hypothetically, as they are in discourse, because reliability is required to consider something true.

Thus, Habermas proposes a relationship of circularity between action and discourse, which he suggests has the potential to produce increasingly high levels of learning because of discourse's role in deproblematizing the failed convictions that result from action. He states:

the theoretical framework has a transcendental function in that it enables learning processes in a certain direction. On the other hand, it remains fundamentally fallible, in that the revisionary power of learning processes may retroactively require a reinterpretation of categories (HABERMAS, 2004a, p. 43).

For Habermas, learning has a practical aspect that forces individuals capable of speaking and acting to continually renew discourse. According to this definition of learning, experience is not a way to imprint meaning (through subjective self-observation), but is treated subjectively by actors who speak and act and, therefore, have certainties and doubts. The world's resistance to individuals' actions creates certainties but also problems. Habermas states: "the contemplative concept of experience makes all margins of constructive criticism disappear, which socialized subjects, in intelligently dealing with a risky and disappointing reality, provide from their life-world to reach successful solutions for problems and learning processes" (HABERMAS, 2004a, p. 41). In other words, practical experience is a space in which disturbed action has the power to activate discourse renewal. Therefore, practice should not be perceived as a way to verify objectivity, but as a space for action that may prove fallible in dealing with the world and therefore should be deproblematized through reason. Habermas explains this (2004a, p. 258) when he says, "in practice, the pre-reflective 'comes to terms with the world' and decides whether the convictions 'work' or whether they fall into the sink of 
questioning, while in arguments, it is only reason that reveals if claims with controversial validity deserve rationally motivated recognition or not". Such is the task of discourse as an epistemological resource: deproblematizing flawed knowledge learned through action using arguments supported by reason.

Basing the epistemological foundation of a group's rational arguments in communicative competence, he discusses the possibility of learning from the world through everyday practices. After identifying the limitations to and practical problems with the solutions offered above, Habermas indicates that knowledge must be revalidated through discourse: "as soon as naive practices are interrupted, claims of validity can only be redeemed discursively, i.e., within the respective context of justification" (2004a, p. 251). What is perceived as unsustainable in action in the world becomes subject to discourse, where it can be deproblematized. According to Habermas, "it is only with the transition from action to discourse that participants adopt a reflective attitude, in light of the pros and cons presented, and dispute the thematized truth of controversial statements" (2004a, p. 49).

The function of discourse is to reflectively assess problematic truths so that they can again enter the realm of action. The deproblematization of truths permits the resumption of a naive attitude in the world, where practical consequences show whether these truths are valid. If the truth reached through discourse is not appropriate for action, it returns to discourse and is discussed again. Once the truth is deproblematized by discourse and reintegrated into action, the individual is able to come to terms with the world (HABERMAS, 2004a). Therefore, successful learning depends on the integration of work in the field of action and the field of discourse, a cycle in which truths are problematized through resistance from the world and deproblematized through reason.

The ways in which this model of reflection proposed by Habermas illuminates the relationship between primary schools and universities as their interaction is called into question are presented below. Difficulties are created by many factors, most obviously in the development of 
research projects, outreach and internships, which are problematized not only by the literature dealing with the subject but also in the statements of the principals interviewed for this study.

\section{Highlighted activities and interactions}

School management, especially the activities and functions performed by the principal (TAUCHEN, 2011; VASCONCELOS, 2009), strongly influences the motivations behind, the mediation of and the monitoring of the relationship between universities and primary schools. Similarly, while performing their functions, principals promote actions and produce speeches and formative cultures (OLIVEIRA, 2005) that strengthen, legitimize, and challenge the contributions of university activities to their schools. Giancaterino (2010, p. 40) notes that management "opens the space for democratic decision-making, as well as capturing and incorporating community resources: students, faculty, staff, parents and others genuinely interested in good school performance". The mobilization of the school community is inextricably connected to the citizens' civil and cultural rights, which, for Habermas (2004b, p. 35), "are rights that guarantee equally, to each and every citizen, access to a tradition and participation in the cultural communities of their choice so that they can establish their identity. This expansion relates to access to a cultural environment." This perspective is used to examine the results of the interactions between schools and universities, which are analyzed through dialogues with the school principals participating in the study.

Through the interviews with the principals, we learned that one of the most successful school-related university activities is the Institutional Scholarship Program for Teaching Initiation [Programa Institucional de Bolsa de Iniciação à Docência - Pibid]. The program, which promotes cooperation among higher education institutions, schools and municipal and state education systems, provides teaching grants to students in undergraduate programs to strengthen 
the ties between future teachers and teaching initiatives in public schools. The program is designed "to encourage the training of teachers for primary education by supporting students that choose a teaching career", especially in areas with the teacher shortages (mathematics and the natural sciences); "to enhance teaching, contributing to raising the quality of public education"; and to promote interaction between higher education and primary education by integrating "undergraduates into the everyday life of schools in the public school system" (BRASIL, 2010). Such goals were articulated in a statement made by one of the principals:

I'm very optimistic about Pibid because I notice that there is an interaction, that the university is very involved with those who have received Pibid. They come to school with an attitude of learning and not the attitude of trying to find a mistake in the school or creating an instrument for debate within the university. The trainees also come with a very technical background; they do not come thinking about the human problems. However, we have learned a lot from the staff of Pibid because we do a roundtable conversation, there is an exchange, an interaction among the teacher, students and the school community (ES).

This quotation describes the intentionality of Pibid's actions, which are not against the school but in favor of the school, thereby changing the focus in the teaching context from diagnostics to formative learning. In addition, the promotion of interaction is not restricted to contact with a single teacher or course, as in most internships, but with the school community in all of its multiplicity and diversity.

Pibid also aims to provide "methodological, technical and practical teaching experiences of an innovative and interdisciplinary nature" in an effort to overcome problems related to the teaching-learning process. It considers school performance, primarily in schools in which the Primary Education Development Index [Índice de Desenvolvimento da Educação Básica - Ideb] is well below the national average, and encourages professors in public schools to become the co-trainers of future teachers. The interviews also revealed positive evidence of these goals: 
The greatest progress, in terms of learning here at school, is Pibid because it is an extensive project. Not a month or two. It's an entire year of activities, even the teacher who is in Pibid speaks very well of it because it has changed her way of working. She is helping the trainees with her own experien$c e$, and they are helping her innovate. She is studying more. Therefore, Pibid has greatly improved the quality of work. Very good, the students like it, we like it, the teachers who are in Pibid are loving it (EFP).

Pibid, by undertaking a set of cooperative and permanent actions, enhances the skills of educators, combining initial and continuous teacher training. One principal also emphasized,

Pibid has continuity, it is ongoing, but I imagine that if for some reason it stops being implemented in school, the teacher, from the university grant, will already have this attitude of innovation in the classroom, in differentiated work. Then, she will continue doing it (ES).

Currently, in some institutions of higher education, Pibid provides almost the same number of scholarships as Scientific Initiation Programs like Pibic. This funding strengthens ties between undergraduate teaching and Primary Education.

Another program mentioned by the principals was the Center for Education [Observatório da Educação], whose aim is to develop educational research. The Center was established in 2006 to "contribute to the creation, strengthening and expansion of sensu stricto graduate programs in the subject of education" and related specialties; "broaden academic and scientific literature on issues related to education"; "support training at the sensu stricto graduate level that enables students to act in the areas of educational policy, educational assessment and teacher training"; promote teacher training; and strengthen the dialogue among the various actors involved in the educational process (BRASIL, 2006).

One of the directors of the Center is contemplating projects that are based on the data produced by the Anísio Teixeira National Institute of Educational Studies and Research [Instituto Nacional de 
Estudos e Pesquisas Educacionais Anísio Teixeira - INEP] and that rely on the following monitoring instruments: Higher Education Census, Census of Basic Education/Educacenso, SAEB, Prova Brasil, IDEB, ESMS, ENADE, National Register of Teachers, and the Register of Institutions and Courses. The Center funds university professors, graduate students, undergraduates and schoolteachers, who form a cooperative network for study and research that circumvents the vertical education structure, as one principal notes:

We have that science project from the Center. The university professors come to the school, both teachers and monitors, in the case of the trainees. They come to the school with the teachers, with management, with the supervisors. They first showed the proposal to the management, the supervisors and later extended it to the teachers. There is commitment from everyone. They are working on the practical part, doing and making things happen (EVC).

Both of the programs discussed by the principals, Pibid and the Center for Education, had, by 2011, funded 283 programs and 153 projects, respectively, throughout Brazil (CLIMACO; NEVES; LIMA, 2012). The principals' remarks showed a desire to expand activities to other areas of knowledge and increase the number of scholarships for primary school teachers because these have been the determining factors in involving teachers in the programs' activities. Without the grants, teachers working 20 hours per week generally take over a second shift and do not have time to participate in research or plan project activities. Moreover, the principals observed that, even with few funded teachers, successful activities spread through the school as changes occurred through interactions with program participants. Such activities were supported by the participation of teachers in the research groups. As stressed by Clímaco, Neves and Lima (2012, p. 190), "for teachers in the primary public education system involved in the studies, the Center represents an opportunity for continuing education and has already registered graduates in professional and 
academic Master's programs [...]". However, because of employment and career conditions, many teachers leave the system after completing graduate school. Thus, the graduate program may not be forming successful frameworks for higher education, even in in this period of institutional expansion, creation and internalization.

The interviewees seemed to suggest that, in many cases, collaboration between universities and schools is consolidated by a mediating subject that moves between these two educational contexts. This mediator has legitimacy with peers in the primary school and is able to combine the demands of public school with the activities promoted by the university. Most noteworthy are the relationships between graduate activities and primary education, which are mediated by teachers in continuing education programs, as the following statement demonstrates: "The school has always sought partnerships. Now we have teachers who are doing their doctorate at the university and who are trying to pursue this partnership" (EZSB). Another principal added,

What we have done a lot of, here at school, is looking for training for teachers, and we have worked with some professors at the University. What we have found to be very useful is for some teachers to talk about topics that help us work with our students. We have some teachers who are still studying at the University, so in some ways we keep in contact (EMA).

Graduate programs allow teachers to participate in research groups (LÜDKE; RODRIGUES; PORTELA, 2012). These groups are spaces forged by cultural pluralism in all regards: in training activities (undergraduates, master's and doctoral candidates, teachers), areas of expertise and teaching, and research and outreach activities. Through this pluralism, a diverse world reveals itself and is interpreted from multiple perspectives, affecting participants' worldviews, self-concepts, and their perceptions of values and personal interests. It is through this multiplicity of interpretive perspectives that egocentric perspectives become decentralized to incorporate the viewpoints of others. For Habermas (2004, p.10), "it is only as participants in a comprehensive 
dialogue that is focused on consensus that we are called to exercise the cognitive virtue of empathy with our mutual differences in the perception of the same situation". Thus, in research groups, individual training projects are linked with group training projects, a strategy in which subjectivity becomes "the realization of epistemological relationships and practices for a person with himself, relations that spring from personal relationships with others and fit within this framework" (HABERMAS, 2004a, p. 12).

Though few in number in the schools studied, it appears that the successful interactions between schools and universities that were facilitated by Pibid, the Center, and graduate programs were able to distinguish themselves from supervised internships, the university activity that received the most criticism from principals:

What we feel in the case of internships is that the student comes and uses the school. It's a friendly relationship because we were lucky to receive interested students who blend well with the school, but when the last day of the internship ends, the relationship ends (EADL).

The internships are perceived as specific activities whose goal is to help the student complete his or her degree; the internships' goals seem to be individual rather than mutually beneficial. Another insight relates to the separation between theory and practice:

What we feel with respect to the university is that it has a lot of theory and little practice. I have a professor who does not need the book to teach, but he does not have control over the class, he does not have a teacher's attitude, the university does not teach a teacher's attitude. And that's it, I do not see this within the university: the theory is quite good, but the practice is non-existent (EALN).

Usually they come to the school when it is to do an internship. The student is very far from reality because you're in college, it's words and paper, it is quite simple. Then, when you fall into reality, when you arrive here and 
the student is hungry, there is a student with family problems, there are several problems involving students, then the curtain that was all adorned in college falls (EALN).

These statements criticize the separation between theory and practice, casting the university as the site of the former and the school as site of the latter. In addition to discussing the meaninglessness of university studies, in which theory seems detached from daily practices in the world and fails to recognize that practice always yields knowledge, a dispute about epistemic authority on educational issues also arose in the interviews. Commenting on this issue, Habermas (2004b, p. 45) wrote, "only language can be the intersubjective bond through which these meanings take shape". Additionally, to the extent that truths are questioned and move from direct involvement in "routines of discourse and action towards a reflective level of reasoning" (HABERMAS, 2004b, p. 62), individuals engage in intersubjective learning through which conflicting viewpoints are decentralized from their egocentric and ethnocentric perspectives. This can occur reciprocally between schools and universities; both engage in the mutual construction of "a broader world of legitimate interpersonal relations" (HABERMAS, 2004b, p. 67) because teaching is the foundational activity in both institutions.

Outreach activities, which are present in almost half of the institutions, appear to be welcomed by the schools because they always complement or enhance the teaching activities being developed:

The study developed since last year, Health and Living, is going very well because teachers are trained and can then train others. It is also well accepted by children, with changes in health, nutrition, and attitude habits (EAC).

We have a project with the university about culture. Students in their fourth and fifth grades come to school when they don't have class to participate in the project, Acrescenta. Since then, they have enjoyed being at school and have come to respect themselves because they work on attitudes and 
habits within this project. Well, this project came ready-made, but we keep in touch with the coordinator, so it is going smoothly (ZPE).

The principals reported that most of the outreach activities focus on collaborating with the students to develop initiatives. Only the Health and Living Project, highlighted by two principals, involves and trains the schoolteachers to participate. Generally, projects "come readymade" to the principals and teachers, who simply supervise them.

A study conducted by Botomé (1996), Pesquisa alienada e ensino alienante: o equívoco da extensão universitária [Alienated research and alienating teaching: the misconception of university outreach], notes that outreach, considered a university activity, acquired legal status through the Statute of Brazilian Universities in 1931. Since then, outreach activities have conducted work that "enhances technical knowledge" but keeps the targeted populations outside the decision-making process. As Botomé (1996, p. 62) reports, "activities (courses and conferences) that would 'bring knowledge to society' were, and seem to remain so today, conducted from the interests of academics or their predominant occupations and according to these interests and occupations".

Outreach is considered a way to give back to society all that it has invested in the university and to remedy the university's lack of communication and intervention in society's problems. Outreach is developed in several ways: in coursework (unsystematic) that disseminates the university's scientific and technical productions; through the provision of social services; by promoting events, charitable activities and communication with the community; and as a supplement to teaching and research activities in which knowledge and actions that would otherwise be restricted to the university as a social-political instrument are shared with the community. The forms of outreach are diverse, but its foundations are not always so.

In the schools studied, approximately the same number of outreach and research activities was being conducted. In most schools, the outreach activities targeted students. The research activities, however, 
were primarily oriented toward teacher training. Clímaco, Neves and Lima (2012) indicated that research is primarily linked to graduate programs. Lüdke, Rodrigues and Portela (2012) suggest that research is an activity that promotes recognition and reciprocity between institutions and the opportunity to participate and grow, "generating a continuous mutuallyenriching movement, recognizing public schools as a privileged space to achieve widespread inseparability between teaching, research and outreach" (LÜDKE, RODRIGUES; PORTELA 2012, p. 207).

These circumstances complicate the interactions between the education levels that comprise the national education system, i.e., primary education and higher education. We consider this system (GARCÍA, 2002; MORIN, 2008) to be a construct that can be understood and analyzed as an organized whole; in other words, it conducts a set of activities as a result of coordination between actions performed by its constituent parts. Therefore, conducting educational reforms at only one level or through only one mode of education will result in few effective changes in the system. Rather, what is needed is reciprocal actions between universities and schools "that modify the behavior or nature" (MORIN, 1997, p. 53) of educational elements or phenomena. Organizing such initiatives requires both physical and discursive contact because primary education and higher education are interdependent levels.

The principals recognized that "the school needs the university because we need teachers who are trained to take over the school" (EALN). However, they experience difficulty finding people, activities and opportunities to partner with the university: "We have not been able to access the university yet. This is the biggest problem. We cannot access the departments to talk to the coordinators, so this is quite difficult" (EADL); "we have a university practically next door and we don't take advantage of it. I do not know who to ask, where to ask, what to ask; I also don't know, I am unaware of what the university has to offer me" (EALN); "I don't know whether the university is not able to see us or if we are not able to reach them" (EHS). These statements reveal the communication difficulties that result from the very structure of the university, which has an extensive 
physical structure fragmented into departments or units but does not disclose to the non-university community the locations of its groups and research centers. It also conducts a variety of teaching activities. Several of the interviewees indicated that communication problems arise from spatiality: it is difficult to find physical access to the schools, even in the case of urban schools.

\section{Interaction between schools and universities: circularity between the epistemological and pragmatic}

As the interviews indicate, primary schools' accessibility to and expectations of the university and the importance of primary schools to university studies must be reconsidered. A reassessment of their proper relationship can be achieved through a proposal for increased collaboration. Habermas proposes a model of learning in which actions and discourses are related in a circular system. As the relationship between schools and universities is conceived of as a space for simultaneous interaction between action and discourse, an interdependent learning process between the two entities emerges. This model decentralizes special interests and reorganizes the actors around a mutual goal of developing successful practices in the world.

When viewed from this perspective, the school-university partnership has the pragmatic knowledge necessary to validate discourse and provides a practical space for knowledge problematization. It becomes a space for exchange between the epistemological and nonepistemological, generating spaces for learning to fulfill the need for experiences with the world. This proposal for circularity ensures that discursive success is inseparable from the certainties reached by actors through their daily practices.

In this circular relationship, the convictions verified through reasoning are transferred to the field of action as practical consequences. If these truths fail to be confirmed by practical experience, they are 
re-forwarded to the discursive realm, where they are reconstituted using new reasons and arguments. The re-assessed convictions are then developed in practice, continually generating a new set of consequences. Thus, a learning cycle is created between the epistemological and the pragmatic that results in the constant renewal of convictions. Such a cycle is necessary because of the fallibility of discourse: "even the arguments that convince us here and now about the truth of " $p$ " may prove false in another epistemic situation" (HABERMAS, 2004a, p. 48). Therefore, discursive truth is confirmed through practice in the world.

The principals' statements about the activities underway in their schools indicate that the university frequently uses the schools' space but does not always meet the schools' expectations. Of the activities discussed, only those performed by the Center for Education and Pibid were seen as making a contribution. This appears to be because both programs seem to effectively combine action and discourse: they improve teaching quality through the initial training provided in undergraduate courses and direct experiences in schools, in which actions are continually problematized. They also deproblematize failed convictions, which are then brought back to the realm of action.

The students participate in other activities in addition to those sponsored by the Center, which is a research-driven program. However, these activities, such as End of Course Study [Trabalho de Conclusão de Curso - TCC) projects, are perceived by the principals as impositions because they seek to address research questions developed independently rather than addressing problems issues that arise organically from research in the schools. One of the interviewees stated, "We are never asked to decide on the projects" (EMRS). Such research is seen as using the school only as a source of data to find solutions to problems that emerged outside of the school. The schools are "not blessed" by the results of the studies because they address problems irrelevant to the schools. The Habermasian model of learning suggests that it is a mistake to use practice only to collect data for a problem developed in discourse because practice should be an indispensible source of problematization. The uselessness of the research 
to the schools denies the researchers' epistemological responsibility to deproblematize knowledge gained through action.

Through research activities, the graduate programs also cooperate with the school; principals reported that their teachers are active in university research groups. In such exchanges, the primary school participates as the owner of knowledge, not just as a recipient. From Habermas's perspective, such role-sharing is fundamental to developing discourse that is successful in action because it is the knowledge of the actors that is examined in discourse.

Supervised internships were identified as contributing the least to the school. Principals believed that interns used the school simply to apply theories that had little relevance to reality. Furthermore, internships use the school to meet the goals of university education without helping the school find solutions to its practical problems. One of the interviewees stated, "We do not have any type of activity that would be an activity where both sides would benefit" (EZSB). Internships, in Habermasian terms, obstruct the relationship between discourse and practice and prevent the achievement of successful practices. Interns do not consider the school as a place where knowledge is tested because the knowledge they bring to the school is understood as an already certified truth.

Outreach was believed to offer some advantages because the projects were developed in the schools. Although outreach does not encourage interaction between primary schools' knowledge and academic knowledge ("the projects are ready-made"), there is technical knowledge being produced that eases the schools' burdens. Outreach consists of preestablished knowledge offered to the schools by the universities, often to compensate for the lack of communication between these entities. One principal interviewed stated, "in these activities, you perceive if they are from research and outreach, they come, perform the activities, and go away, they do not provide feedback" (EAN). In such cases, the school is used as a space to apply ready-made knowledge, and no structure is provided so that the activities can be continued by members of the school. According to Habermas, because discourse must be tested by application in the world, 
the universities' approach exhibits their disregard for practical knowledge and problems. Thus, learning is hampered by the universities' lack of involvement and commitment to the schools' problems and knowledge.

These findings demonstrate that although universities have promoted some mutually beneficial interactions, their relationships with primary schools, especially with regard to internships, research and outreach, are inadequate. To overcome their negative image, universities should act on their epistemological commitment to addressing practical problems by providing more positive experiences and increasing their accessibility while maintaining respect for school practices. As one interviewee expressed, "the university is very closed. The university does not open its space, except only when it needs to because within the university, few professors put themselves in our shoes. There are a lot of people there on their high horse all the time" (EALN).

This outburst characterizes the university's vertical approach to schools in which the university is the only source of knowledge. Universities are rarely interested in questioning knowledge through experience with the world or deproblematizing practical knowledge through discourse. In the circular model proposed by Habermas, learning is incomplete when it is limited to discourse. In universities, discourse is produced through problematizations and truths that are disassociated from practice, and primary schools are treated only as spaces for application. The subjects and their practices are not seen as participants in the learning process because they are not offered a space for interaction and questioning, and their knowledge is almost always disregarded. Therefore, despite universities' engagement with schools, they do not use school to explore the lessons to be learned from experience in the world and continue to perpetuate the belief that learning happens only in the university.

The university brings already-legitimized knowledge to the school that is not open to criticism or refutation. Schools are not used to certify discourse through action, but only as spaces in which to present knowledge that is already accepted as truth in discourse. Habermas, in contrast, asserts that discourse, however well argued, should also 
be able to guarantee its effectiveness through action. Otherwise, there is no guarantee of its validity or its fallibility. For Habermas (2004a), discourse is the opportunity to legitimate practical successes through reason, but practice is the opportunity to verify the truth of discourse through experience with the world. Therefore, he considers learning to be a continuous cycle between discourse and action.

For successful learning, activities should be developed that combine actions and discourse to verify pragmatic truths through epistemological exploration. Interactions between schools and universities make university discourse the space in which failed actions are adjusted and tested; it is a discursive environment with a scientific and social responsibility to deproblematize flawed knowledge gained from experiences in primary schools. According to Habermas (2004a, p. 50), discourse should be "set in the context of the practices of the life-world because they have the function of restoring agreement in a partially disturbed background." Thus, the university should not be seen as the sole certifier of knowledge but should use the knowledge gained from practice to verify discursive truths. Thus, in this model, establishing truth depends both on the certainties of action and the successes achieved in discourse. Trevisan critically analyzes the consequences of this circular relationship:

In the case of the school's relationship with the university, there cannot be subservience: the school cannot simply be seen as a field for practical application of knowledge or professional development of strategies. Neither can it be evaluated as a mediating center of "unity" between theory and practice, but more so as an area able to produce legitimate knowledge. Recognizing a theory production field within the school causes the confrontation between professor training and the schoolteacher's training to become an absolute necessity. The university will avoid, in this sense, finding outlets or subterfuges to conceal this relationship, such as the creation of Bachelor's degrees. And, on the side of the school, there will be greater responsibility for the training of interns, who are, for example their future teachers (2011, p. 208). 
Circularity between actions and discourse, understood here as circularity between the school and the university, is sustained through the perpetual translation of certainties from practice into problematized convictions, and from problematized convictions into reestablished certainties. Schools can provide the necessary testing of the discursive justifications through their relationship with the university, maintaining "alertness between interlocutors in the awareness of the fallibility of our interpretations" (HABERMAS, 2004a, p. 258). Additionally, rational communication conditions could guarantee the continued renewal of problematized convictions. In a cyclical relationship, knowledge is not centralized in either the school or the university, but in the combination of the two spheres of truth, each playing an important role in the learning process.

\section{Final considerations}

The suggestions for promoting more effective interactions between universities and primary schools, especially with regard to the deproblematization of practical knowledge, helps redefine the university's role. These suggestions are inspired by Habermas's proposals for improving the coordination between actions and discourse or, in other words, the school and university, making them participants in the same learning process, each collaborating with the other in the renewal of knowledge.

The implications of this analysis have the potential to a) unite the universities and schools through a common objective. Currently, both entities are integrated into the national education system but are located at different levels and experience the influences of the system's organization and maintenance policies differently; b) demonstrate that the organization of educational activity occurs through democratization, decentralization and exchange of individual perspectives and interpretations. The school management, especially the school 
principal, plays a key role in fostering interactions and arguments; c) continuously and progressively publicize educational initiatives developed in universities and schools and increase their inclusion of one another; d) expand and create new spaces for communicative interaction; e) promote research approaches based on communicative action, for example, through action-research and training roundtables.

This study describes a paradigm in which the school and the university engage in a collaborative learning process. Such interaction is possible because both entities serve as fields of action in which discourse is problematized and as epistemological fields in which such problematic issues are discussed through reason. Thus, an epistemologically inextricable connection is established between actions and discourse that facilitates the constant renewal of knowledge. In this paradigm, the school is no longer perceived simply as a space for application and becomes an environment for problematizing already established certainties. The university encounters many obstacles, from only being observed as seeking meaning from the school and monopolizing the authority to certify practical knowledge to only being committed to deproblematizing faulty knowledge. This can be resolved by reserving an epistemological-pragmatic role for the intermediate space between schools and universities, a step that promises to produce increasingly advanced levels of learning.

\section{Acknowledgements}

Capes/Inep; FAPERGS; CNPq.

\section{References}

BARDIN, L. Análise de conteúdo. Lisboa: Edições, 1977. 
CLÍMACO, J. C. T. S.; NEVES, C. M. C.; LIMA, B. F. Z. Ações da Capes para a formação e a valorização dos professores da educação básica do Brasil e sua interação com a pós-graduação. RBPG, v. 9, n. 16, p. 181 - 209, abril de 2012.

BRASIL. Decreto n. 5.803, de 8 de junho de 2006. Dispõe sobre o Observatório da Educação, e dá outras providências. Diário Oficial da União, Brasilia, DF, 9 jun. 2006. p. 5.

BRASIL. Decreto n. 7.219, de 24 de junho de 2010. Dispõe sobre o Programa Institucional de Bolsa de Iniciação à Docência - PIBID e dá outras providências. Diário Oficial da União, Brasilia, DF, 25 jun. 2010. p. 5.

BOTOMÉ, S. P. Pesquisa alienada e ensino alienante: o equívoco da extensão universitária. Petrópolis: Vozes, 1996.

FRANCO, M. L. P. B. Análise de conteúdo. 3. ed. Brasília: Líber Livro, 2008.

GARCÍA, R. O conhecimento em construção: das formulações de Jean Piaget à teoria dos sistemas complexos. Porto Alegre: Artmed, 2002.

GIANCATERINO, R. Supervisão escolar e gestão democrática: um elo para o sucesso escolar. Rio de Janeiro: Wak, 2010.

HABERMAS, J. Verdade e justificação: ensaios filosóficos. São Paulo: Loyola, 2004a. HABERMAS, J. A ética da discussão e a questão da verdade. São Paulo: Martins Fontes, 2004b.

LÜDKE, M.; RODRIGUES, P. A. M.; PORTELA, V. C. M. O mestrado como via de formação de professores da educação básica para a pesquisa. Revista Brasileira de Pós-Graduação, v. 9, n. 16, p. 59 - 83, abr. 2012.

MINAYO, M. C. Pesquisa social: teoria, método e criatividade. Petrópolis: Vozes, 2001.

MORIN, E. Ciência com consciência. 11. ed. Rio de Janeiro: Bertrand Brasil, 2008. OLIVEIRA, M. A. M. et al. (Org.). Gestão educacional: novos olhares, novas abordagens. 4. ed. Petrópolis: Vozes, 2005. 
TAUCHEN, G. (Org.). Gestão Educacional. Rio Grande: Editora da FURG, 2011. v. 3. TREVISAN, A. L. Filosofia da Educação e formação de professores no velho dilema entre teoria e prática. Educar em Revista, n. 42, p. 195-212, out./dez. 2011. Available at: 〈http://www.scielo.br/pdf/er/n42/a13n42.pdf〉. Accessed in: Aug. 182012.

VASCONCELLOS, C. S. Coordenação do trabalho pedagógico: do projeto político pedagógico ao cotidiano da sala de aula. 11. ed. São Paulo: Libertad Editora, 2009.

Received: 05/21/2013

Recebido: 21/05/2013

Approved: 03/20/2014 Aprovado: 20/03/2014 